\title{
Reflective Thinking, A New Skill in English Pedagogy Curriculum at Playa Ancha's University
}

\author{
Mg. Erika Loreto Diaz S. \\ Mg. Amanda Isabel Vasquez
}

\begin{abstract}
This study is part of a doctoral research, which aim is to prove that reflective thinking can be developed and scaffolded during teacher training, through the introduction of diverse active methodologies practice in the university classroom; such as writing a reflective diary, dialoguing with in-service teachers, and becoming a teacher assistant. Consequently, the researchers applied the action research cycle to motivate future teachers to keep a reflective journal about their experiences throughout their career. As a conclusion, all the strategies applied have contributed to accomplish the research's main goal.
\end{abstract}

Keywords: reflective thinking, teacher training, action research.

\section{Introduction}

It is worldwide recognized the need of improving the processes of initial teacher training. In this regard, Chacón (2008) states that it is necessary for students in their educational careers to acquire tools that help them to develop reflective thinking. This ability allows the individual to understand the complexity of the classroom. In this context, the following research proposes to promote the acquisition process of reflective thinking in the students of English Pedagogy at Playa Ancha's University, Valparaíso, Chile. This process will be developed through the activities planned for the subject called Initial Workshop for Practice (TIFP in Spanish). Authors such as Chacón (2005, 2008), Chacón \& Sayago (2005), Pérez (2010) and Tallaferro (2005) argue that such approaches should start from the first moments of the pedagogical career. This paradigm recognizes that reflective practice should take place in active and real spaces. That's why this research is developed through the axis of early school practices encouraging reflection on trainer teachers' vocation and pedagogical work, from their earliest years of formation.

\section{The Problem}

This research's problem arises from the results of the last evaluations applied to the teachers of Chilean public schools, which shows the lack of reflection in a high number of teachers (Docentemás 2012) ${ }^{1}$. Consequently, the reports of the Tuning project for Latin America (2004) $)^{2}$ and the OECD, propose curricular renewals in initial teacher training. This information is collected by the Playa Ancha's University in its process of curricula innovation of pedagogy careers, and incorporates reflective thinking as an ability to be developed through the axis of practices. However, this paradigm shift confronts us with new challenges, and as Domingo (2013) puts it, in this scenario we lack formal and proven on-site strategies that efficiently and effectively promote reflective thinking in pedagogy students in their Early Practices. Therefore, the research question is what methodological strategies efficiently promote the development of reflective teaching thinking in UPLA's students of English pedagogy?

\section{General Objective}

Elaborate a methodological proposal to develop reflective teaching thinking skill among English Pedagogy students at Playa Ancha's University, under the context of curricula innovation.

\section{Specific Objectives}

1) Scaffold the development of reflective teacher thinking ability through various methodological strategies applied at the core of early practice.

2) Monitor the implementation of the proposal semester to semester through the action research cycle.

\footnotetext{
${ }^{1}$ Www.docentemas.cl

${ }^{2}$ http://www.sg.inter.edu/uploads/UIPRSG/documentos/asuntos_academicos/RevisionPEG/Proyecto\%20Tuning\%20America \%20Latina_Informe\%20Final_Espanol_2007.pdf
} 


\section{Hypothesis:}

Teaching reflective thinking will be developed during the initial training process, through methodological strategies of continuous support, therefore to greater guided methodological practice, the greater the reflective capacity developed by the student of pedagogy.

\section{Proposal:}

Understanding reflective teacher thinking as a cognitive ability to be improved, this research raises a methodological proposal based on the models of Korthagen (1985), Kolb and Fry (1975) Ziechner and Liston (1996) and Farrel (2004, 2007) whose focus is the development of the skill through a series of strategies graded in complexity. Under this paradigm, Farrell (2004), Jay and Johnson (2002) and VanMannen (1977), have stipulated that the reflexive process has three levels: descriptive, comparative and critical. Then, since this study covers a period of 8 semesters, the level of the reflexive ability is classified according to the annual progress of the students of the sample, that is to say, advancing one level for every two semesters through the practice program, as shown in figure 1.

Consequently, this research takes Schön (1992) as reference, who stipulates that professional development depends on experience, practice and reflection. Schön proposes to develop this ability in the different practices that the student experiences during his teacher training, to transform it into a permanent practice competency of the future teacher.

\section{Sequence of the Intervention Plan}

\begin{tabular}{|c|c|c|c|}
\hline TERM & EXPECTING LEARNING OUTCOME & INTERVENTION STRATEGY & REFLECTION LEVEL \\
\hline I & $\begin{array}{l}\text { Understanding the concept of reflective } \\
\text { thinking }\end{array}$ & Writing Your First Reflective Diary & Descriptive \\
\hline II & $\begin{array}{l}\text { Develop reflection through dialogue with } \\
\text { others }\end{array}$ & $\begin{array}{l}\text { Pedagogical dialogues with local school } \\
\text { system teachers }\end{array}$ & Descriptive \\
\hline III & $\begin{array}{l}\text { Develop observation skills to understand } \\
\text { pedagogical phenomena in the classroom }\end{array}$ & Observation as a strategy of reflection & Descriptive and comparative \\
\hline IV & $\begin{array}{l}\text { Apply classroom observation techniques to } \\
\text { reflect on factors that influence school life }\end{array}$ & $\begin{array}{l}\text { First intervention in school working with a } \\
\text { group of students for } 8 \text { weeks }\end{array}$ & Comparative \\
\hline $\mathbf{V}$ & $\begin{array}{l}\text { Apply qualitative research methods as a } \\
\text { strategy for the development of pedagogical } \\
\text { reflection }\end{array}$ & Action research as a reflection strategy & Comparative \\
\hline VI & $\begin{array}{l}\text { Create, apply, analyze and reflect on a } \\
\text { pedagogical intervention in its disciplinary } \\
\text { area }\end{array}$ & $\begin{array}{l}\text { Disciplinary methodological intervention } \\
\text { in school }\end{array}$ & Critical - Comparative \\
\hline VII & $\begin{array}{l}\text { Design, participate and reflect reflexively } \\
\text { on a collaborative disciplinary classroom } \\
\text { project }\end{array}$ & $\begin{array}{lll}\begin{array}{l}\text { Project-based } \\
\text { assistant }\end{array} & \text { learning. } & \text { Classroom } \\
\end{array}$ & Critical \\
\hline VIII & $\begin{array}{l}\text { Reflectively evaluate of pedagogical } \\
\text { performance }\end{array}$ & Writing Your First Reflective Diary & Critical \\
\hline
\end{tabular}

Figure 1: The annual progress of the sample's students.

\section{Findings:}

The students of the sample have acquired the ability to reflect on their pedagogical practice, advancing in the levels of reflection according to the development of their teacher training. Thus, both the researchers and the participating population recognize that putting the focus in classroom practice supports the development of this skill.Similarly, it is proven that the earlier this training process begins, the better the achievement of the competition's development. It is concluded that the objectives were achieved and the hypothesis could be verified

\section{Projections and Limitations:}

At this stage of the research it can be inferred that the improvement of the implementation through the cycle of research-action causes that the students of the sample develop their reflective thinking in a better way.

At the beginning of the process the reflection of the sample is basic, demonstrating confirmation that the practice in real educational scenarios develops the student reflective thought effectively. Under the same paradigm the projections are related to the continuity of the proposal in the new generations of Englishpedagogy's students at UPLA, with projections towards to the other pedagogies at the same University. On the other hand, the limitations relate to the school placements available for early practices, which instead of increasing, decrease every single semester.

\section{References}

Berg, B.L. (2006). Qualitative Research Methods for the Social Sciences. Pearson. 
Bodgan, R.C. and Knopp Biklen, S (2003). Qualitative Research for Education.An Introduction to Theories and Methods.Pearson.

Chacón, M. A. (2008). Las estrategias de enseñanza reflexiva en la formación inicial docente. Educere, $\mathrm{N}^{\mathbf{0}} 41$, disponible en http://www.saber.ula.ve/handle/123456789/20248.

Chacón Corzo, M. (2005). La reflexión y crítica en la formación docente. Universidad de Los Andes. San Cristobal: EDUCERE.

Chacón Corzo, M. A., Sayago Quintana, Z. B., \& Molina Yuncosa, N. L. (2008). Comunidades de aprendizaje: un espacio para la interacción entre la universidad y la escuela. Revista de Teoría y Didáctica de las Ciencias Sociales, 13, 9-28.

Domingo, A. (2013). El método R5 de Práctica Reflexiva. Evaluación de su impacto en la formación inicial de maestros. Innoeduca.International Journal of Technology and Educational Innovation, [S.I.], v. 4, n. 1, p. 4-13, jun. 2018.ISSN 2444-2925. Disponible en: www.revistas.uma.es/index.php/innoeduca/article/view/4666

Jay, J. \& Johnson, K.(2002). Capturing complexity: a typology of reflective practice for teacher education.Teaching and Teacher Education. 18: 73-85.

Farrell, T. S. C (2012). Reflecting on reflective practice: (Re) visiting Dewey and Schön.TESOL Journal 3 (1): 7-16.

Farrell, T. S. C (2014). Reflective practice in ESL teacher development groups: from practices to principles. Bassinstoke, UK: Palgrave Mac Millan.

Farrell, T. S. C (2015). Promoting teacher reflection in second language education.A framework for TESOL professionals. ESL \& Applied Linguistics Professionals Series. Routledge.

Jay, J. \& Johnson, K.(2002). Capturing complexity: a typology of reflective practice for teacher education.Teaching and Teacher Education. 18: 73-85.

Korthagen, F. A. J., \&Vasalos, A. (2005).Levels of reflection: Core reflection as a means to enhance professional growth. Teachers and Teaching: Theory and Practice, 11 (1), 4-17.

Korthagen, F. A. J., \&Vasalos, A. (2010).Going to the core: Deepining reflection by connecting the person to the profession. In N. Lyons (Ed), Handbook of reflection and reflective inquiry: Mapping a way of knowing for professional reflective inquiry (pp. 529-552). New York: Springer.

Pérez, A. (2010). Nuevas exigencias y escenarios para la profesión docente en la era de la información y de la incertidumbre. Revista Interuniversitaria de Formación del Profesorado no 68 (2010), pp. 17-36.

Schön, D. (1987). La formación de profesionales reflexivos. Barcelona: Paidós.

Schön, D. (1994). La formación de profesionales reflexivos. Hacia un nuevo diseño de la enseñanza y el aprendizaje en las profesiones. Barcelona: Paidós.

Schön, D. (1998). El profesional reflexivo; cómo piensan los profesionalescuando actúan. Temas de educación.Barcelona. Paidós.

Spilkova, V. (2001).Professional development of teachers and students teachers through reflection on practice.EuropeanJournal of Teacher Education. 24: 59-65.

Tallaferro, D. (2006). La formación para la práctica reflexiva en las prácticas profesionales docentes. Artículosarbitrados n $n^{\circ} 33,2006$; PP. 269-273.

Ward, J. \&Mc Cotter, S. (2004). Reflection as a visible outcome for preservice teachers.Teaching and Teacher Education 20, 2004; pp. 243-257.Disponible en: www.elsevier.com.

Zeichner, K.M, \& Liston, D.P. (1987).Teaching student teachers to reflect.Harvard Educational Review.Vol.57 (1). 